\title{
8
}
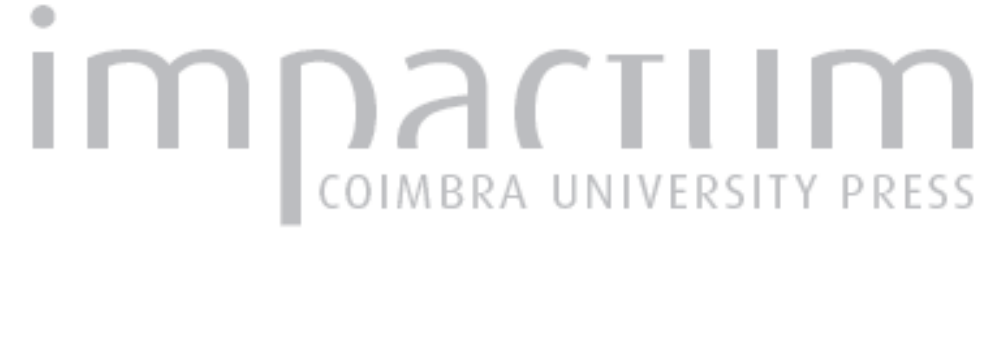

Considerações críticas sobre o humanismo marxista na perspectiva da antropologia cristã
Autor(es):
Alves, Cleber Francisco
Publicado por:
Universidade Católica de Petrópolis; Instituto Brasileiro de Informação em Ciência e Tecnologia

URL

persistente:

DOI: $\quad$ DOI:http://dx.doi.org/10.14195/1984-6754_4-2_2

Accessed : $\quad$ 26-Apr-2023 06:49:02

A navegação consulta e descarregamento dos títulos inseridos nas Bibliotecas Digitais UC Digitalis, UC Pombalina e UC Impactum, pressupõem a aceitação plena e sem reservas dos Termos e Condições de Uso destas Bibliotecas Digitais, disponíveis em https://digitalis.uc.pt/pt-pt/termos.

Conforme exposto nos referidos Termos e Condições de Uso, o descarregamento de títulos de acesso restrito requer uma licença válida de autorização devendo o utilizador aceder ao(s) documento(s) a partir de um endereço de IP da instituição detentora da supramencionada licença.

Ao utilizador é apenas permitido o descarregamento para uso pessoal, pelo que o emprego do(s) título(s) descarregado(s) para outro fim, designadamente comercial, carece de autorização do respetivo autor ou editor da obra.

Na medida em que todas as obras da UC Digitalis se encontram protegidas pelo Código do Direito de Autor e Direitos Conexos e demais legislação aplicável, toda a cópia, parcial ou total, deste documento, nos casos em que é legalmente admitida, deverá conter ou fazer-se acompanhar por este aviso. 

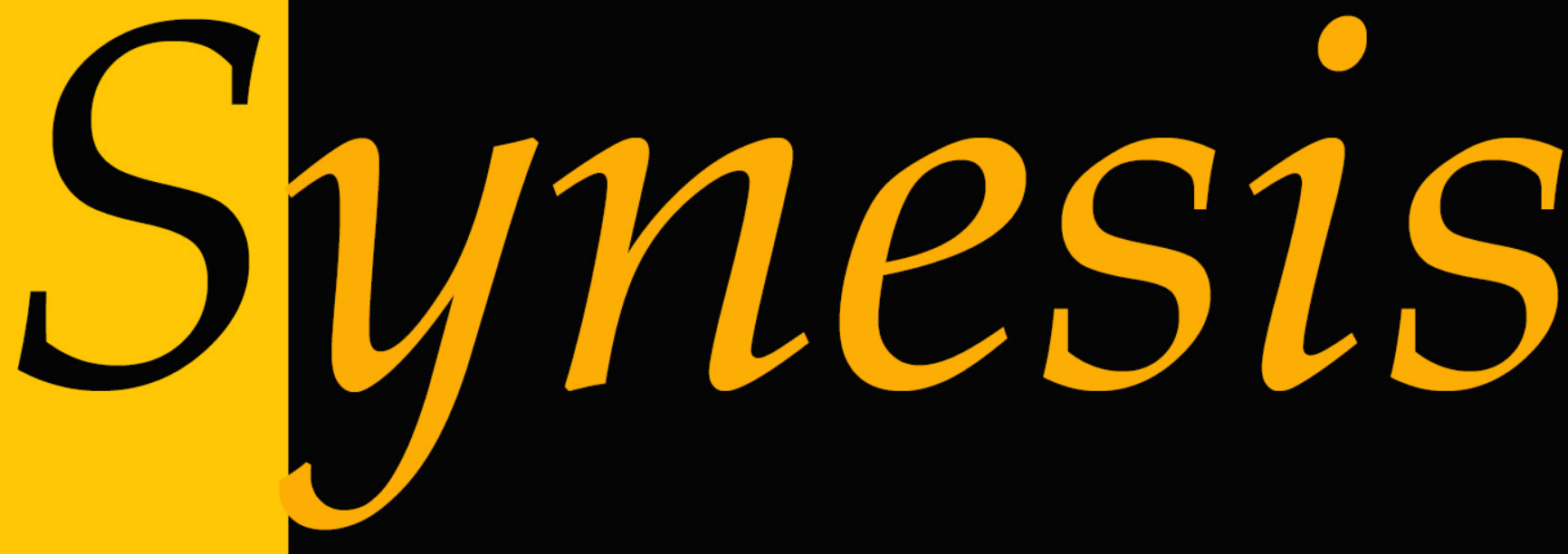

Revista do Centro de Teologia e Humanidades ISSN 1984-6754

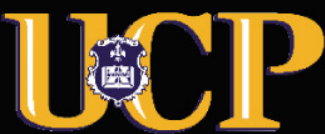




\title{
CONSIDERAÇÕES CRITICAS SOBRE O HuMANISMO MARXISTA NA PERSPECTIVA DA ANTROPOLOGIA CRISTÃ
}

\section{CRITICAL CONSIDERATIONS ON MARXIST HuMANISM IN THE PERSPECTIVE OF CHRISTIAN ANTHROPOLOGY*}

\author{
Cueber Franctsco Alves" \\ Univeramade Catótica de Petrópolis, Brasil
}

Resumo: No presente trabalho buscou-se realizar uma pesquisa a respeito de algumas características elementares do humanismo na tradição marxista - particularmente reveladas por Marx nas suas obras de juventude - e bem assim procurou-se efetuar um levantamento da crítica que lhe tem sido oposta por autores comprometidos com uma visão antropológica cristã.

Palavras-chave: Antropologia; Humanismo cristão; Karl Marx.

Abstract: This work attempted to condut a research about elementary character of humanism in marxist tradition - particularly revealed by Marx in his youth works - so attempted to make a survey of criticism which has been opposed by authors committed to a christian anthropological view.

Keywords: Anthropology; Christian humanism; Karl Marx.

\footnotetext{
* Artigo recebido em 22/11/2012 e aprovado para publicação pelo Conselho Editorial em 15/12/2012.

** Doutor em Direito pela Pontifícia Universidade Católica do Rio de Janeiro. Professor e Coordenador do Mestrado em Direito da Universidade Católica de Petrópolis; Professor Adjunto da Faculdade de Direito da UFF, Defensor Público do Estado do Rio de Janeiro. Currículo Lattes: http://lattes.cnpq.br/1404410751990175. E-mail: cleber.alves@ucp.br.
} 


\section{Introdução}

Numa retrospectiva acerca dos temas fundamentais sobre os quais centrou-se o pensamento humano, na história da filosofia do mundo ocidental, poder-se-ia reconhecer, a grosso modo, que primeiramente - entre os helênicos - havia uma preocupação em explicar o cosmos, ocupando-se os filósofos de investigações acerca da constituição da matéria, sobre o processo e a(s) causa(s) que explicassem a natureza e a ordem do universo. Mais adiante, o pensamento medieval caracterizou-se por dedicar especial atenção ao problema teológico, explicando sob essa perspectiva transcedental as temáticas do homem e do universo. Finalmente, parece inequívoco que o homem passou a ocupar uma posição proeminente no pensamento da era moderna: assim, sob essa ótica antropológica passaram a ser considerados os temas da valoração do cosmos e até mesmo as questões relativas à Deus.

Esse "humanismo", que tornou-se uma constante no pensamento dos principais filósofos da modernidade, não é, sem dúvida, unívoco e homogêneo. Pelo contrário, como salienta o Prof. Pedro Nogare, a expressão comporta diversos sentidos. Segundo esse autor (1983, pp. 15-16)

uma doutrina e sobretudo uma determinada situação histórica podem ser qualificadas de humanistas só na medida em que, reconhecendo o homem como um ser de longe superior a todos os outros seres, nele vêem o objetivo e meta de todas as atividades e de todas as instituições, no sentido de possibilitar-lhe a realização mais plena e perfeita possível de sua humanidade e personalidade, isto é, de sua liberdade.

Assim, as diversas correntes humanistas, enquanto se propõem a oferecer caminhos concretos que permitam a efetiva realização do homem, interpretando de variadas maneiras o critério último a ser considerado para o alcance desse desiderato, assumem posições muitas vezes antagônicas e inconciliáveis, dando ensejo às distintas concepções de humanismo presentes nos nossos dias.

Como ensina Andrew Woznicki (1988), um humanismo autêntico tem sempre que tratar as questões fundamentais da dignidade e do valor intrínseco de cada ser humano. $\mathrm{O}$ êxito dessa abordagem somente seria alcançado enquanto fosse capaz de receber um tratamento eqüidistante entre dois extremos: teocentrismo e antropocentrismo. Nas palavras desse mesmo autor, "se enfocamos o problema da dignidade do homem sob um ponto de vista exclusivamente teocêntrico, com facilidade podemos perder de vista o homem, se nossa postura é rigidamente antropocêntrica, negamos o divino” (WOZNICKI, 1988, p. 19). 
Tendo em vista a importância dessa problemática do humanismo e diante das instigantes questões práticas que o tema suscita, e considerando ainda que a compreensão da natureza e dignidade da pessoa humana é um desafio que sempre tem instigado o pensamento humano, através do presente ensaio se buscou realizar uma pesquisa a respeito de algumas características elementares do humanismo na tradição marxista - particularmente reveladas por Marx nas suas obras de juventude - e bem assim procurou-se efetuar um levantamento da crítica que lhe tem sido oposta por autores comprometidos com uma visão antropológica cristã.

\section{O Humanismo no Pensamento Marxista}

$\mathrm{Na}$ raiz do projeto humanista arquitetado por Karl Marx está a pretensão de resgatar o homem das multiplas formas de alienação que, de certa forma, o escravizam, privando o ser humano de sua própria essência. Etimologicamente alienar significa tornar alheio, e alienar-se quer dizer tornar-se outro. Pela alienação, no sentido marxista, o homem torna-se estranho a si mesmo, separa-se de seu próprio ser. A alienação leva o homem a despojar-se de sua realidade, daquilo que lhe é intrínseco, chegando mesmo a criar falsas entidades fora de si como uma espécie de compensação.

Essa idéia de alienação chegou a Marx a partir da filosofia de Hegel, sendo que tal conceito foi desenvolvido em profundidade por Feuerbach. Todavia a teoria da alienação em Feuerbach centrava-se radicalmente na dimensão religiosa, enquanto que para Marx, como teremos a oportunidade de ressaltar mais adiante, a origem de toda alienação encontrava-se na dimensão econômica.

Feuerbach era discipulo de Hegel, de quem Marx também recebeu grande influência sobretudo no período em que estudou na Universidade de Berlim. O hegelianismo era o pensamento dominante na Alemanha nas primeiras décadas do século XIX. Após a morte do mestre, seus discípulos se dividiram em duas correntes, sendo que Marx integrou-se à chamada "esquerda hegeliana", de inspiração anti-religiosa e atéia. Foi culminante no pensamento desse grupo - também chamado de "Jovens Hegelianos" - a publicação, em 1841, da obra "A essência do Cristianismo", onde Feuerbach formula uma intensa crítica da filosofia da religião. Nesta obra o autor contesta o idealismo de Hegel, assumindo uma postura materialista que terá influência marcante no pensamento marxista. Feuerbach propõe um humanismo ateu onde consagra sua teoria da alienação religiosa, e reivindica para o homem o 
lugar que estaria sendo atribuído a Deus. O entusiasmo de Marx pelas propostas feuerbaquianas ficou registrado na obra "A Sagrada Família", escrita em co-autoria com Friedrich Engels (1971, p. 111), tal como se pode observar no ardor destas palavras:

...quem aniquilou, pois, a dialética das idéias, a guerra dos deuses unicamente conhecida pelos filósofos? Quem colocou, portanto, a "importância do homem" - como se o homem tivesse outra importância, a não ser a importância que a de ser homem! - ou ao menos o homem no lugar da velha confusão, até a "consciência infinita do eu"? Feuerbach e só Feuerbach. E há mais, ainda. Faz bastante tempo que aniquilou essas categorias, com as quais a crítica brinca atualmente, "a verdadeira riqueza das relações humanas, o fundo imenso da história, a luta da massa contra o espírito, etc. ${ }^{1}$

Feuerbach concebeu o fenômeno religioso como uma ilusão, um produto da imaginação do homem que ao projetar para fora de si seus desejos - daí a noção de alienar-se! - lhes objetiva num ser fantástico, ao qual dá o nome de Deus. Como assinala o grande teólogo Henri de Lubac (1945), para Feuerbach Deus é apenas o "conjunto de atributos" que fazem a grandeza do homem. Segundo o filósofo alemão, se a "divindade da natureza" está na base de todas as religiões, inclusive do cristianismo, a "divindade do homem" é sempre a meta final: a virada da história se dará no momento em que o homem tomar consciência de que o único Deus do homem é o próprio homem: Homo bomini Deus.

Portanto, para Feuerbach, projetou-se em Deus, na vida eterna, aquilo que a humanidade deveria ser na consciência do homem. Operou-se uma transferência da grandeza da humanidade no mito da religião. A (re-)conciliação do indivíduo com o gênero humano somente se fará quando a pessoa re-encontrar a humanidade em si mesma, recuperando o que lhe fora "espoliado" pela religião.

Após o momento inicial de entusiasmo com a proposta feuerbaquiana, Marx reformulou seu pensamento, passando a apontar uma falha que considerava crucial nas conclusões desse filósofo: ao formular um ateísmo "especulativo", Feuerbach teria permanecido ainda muito preso ao idealismo, estava muito apegado à abstração, buscava uma "cura" de ordem psicológica para os males do homem. Não! O que Marx concebe é um "autêntico" materialismo, que radica na praxis, na realidade sensível, no mundo das relações

\footnotetext{
${ }^{1}$ No original: ¿Quién ha aniquilado, pues, a la dialéctica de las ideas, a la guerra de los dioses únicamente conocida por los filósofos? ¿Quién há puesto, pues, "la importancia del hombre" — como si el hombre tuviera otra importancia que la de ser hombre!- o al menos al hombre en el lugar del viejo fárrago, hasta a la "conciencia infinita del yo"? Feuerbach y sólo Feuerbach. Y ha hecho más todavía. Desde hace bastante tiempo ha aniquilado esas categorías, con las cuales la crítica juguetea actualmente, "la verdadera riqueza de las relaciones humanas, el fondo inmenso de la historia, la lucha de la historia, la lucha de la masa contra el espíritu, etc.".
} 
sociais em que toma parte o homem. Lemos em "A Ideologia Alemã" a censura que Marx e Engels (1996, pp. 69-70) fazem a Feuerbeach, porque ele

\begin{abstract}
...permanece no reino da teoria e não concebe os homens em sua conexão social dada, em suas condições de vida existentes, que fizeram deles o que são; por isto mesmo, jamais chega até os homens ativos realmente existentes, mas se detém na abstração "o homem" e apenas consegue reconhecer sentimentalmente o "homem real, individual, corporal", isto é, "não conhece outras relações humanas" "entre o homem e o homem" senão as do amor e da amizade, sendo estas, além disso, idealizadas. Não nos oferece crítica alguma das condições de vida atuais. Não consegue nunca, portanto, conceber o mundo sensível como a atividade sensível, viva e total, dos indivíduos que o constituem, razão pela qual é obrigado, ao ver, por exemplo, ao invés de homens sadios um bando de pobres-diabos, escrufulosos, esgotados e tísicos, a recorrer a uma concepção superior"e à ideal "igualização no gênero"; ou seja, por conseguinte, a reincidir no idealismo precisamente ali onde o materialista comunista vê a necessidade e simultaneamente a condição de uma transformação, tanto da indústria como da estrutura social. ${ }^{2}$
\end{abstract}

Dentro dessa perspectiva radicalmente materialista, Marx vai afirmar que a origem, a raiz de toda alienação está na maneira de produzir, no processo econômico efetivamente verificado na sociedade real. Dessa alienação econômica é que derivam todoas as demais formas de alienação, inclusive a religiosa. Portanto, a "redenção" do homem estaria na destruição da causa dessa alienação econômica, que é, em última análise, o modo de produção capitalista, baseado na propriedade privada, que subtrai do homem aquilo que tem de mais essencial: seu trabalho representado pela atividade sensível sobre a natureza.

Entretanto, voltando à questão da religiosidade, deve-se ressaltar que Marx jamais abandonou uma postura radicalmente atéia, externando sempre que possível uma repugnância visceral a todas as formas de religião, sendo célebre a sua máxima que afirma ser a religião o "ópio do povo"3. Marx considerava que a religião, particularmente o cristianismo, traduzia-se numa forma de exploração capitalista, na medida em que pregava a resignação perante as

\footnotetext{
${ }^{2}$ Essa ruptura com o pensamento de Feuerbach fica ainda mais explícita nas "Teses sobre Feuerbach", que estão publicadas em anexo à Ideologia Alemã, valendo ressaltar a Tese $\mathrm{n}^{\circ}$ VI, que diz: "Feuerbach dissolve a essência religiosa na essência humana. Mas a essência humana não é uma abstração inerente ao indivíduo singular. Em sua realidade, é o conjunto das relações sociais."

${ }^{3} \mathrm{~A}$ influência de Feuerbach fica patente também neste famoso trecho, da obra "Introdução à crítica à Filosofia do Direito de Hegel", escrito por Marx: "O homem faz a religião, a religião não faz o homem. A religião é a consciência de si e o sentimento de si do homem que ainda não se conquistou ou já se perdeu. A miséria religiosa é, ao mesmo tempo, a expressão da miséria real e o protesto contra essa miséria... A religião é o ópio do povo. O desaparecimento da religião como felicidade ilusória do povo é uma exigência de sua felicidade real. A religião é apenas um sol fictício que se desloca em torno do homem enquanto este não se move em torno de si mesmo" (apud ARDUINI, Côn. Juvenal. O Marxismo. Rio de Janeiro, Agir, 1965. p. 40)

http:// seer.ucp.br/seer/index.php?journal=synesis
} 
injustiças sociais, na expectativa de uma premiação futura na vida eterna que, para ele, era um engodo.

Enfim, diante dessas múltiplas formas de alienação do homem, buscando realizar um "autêntico" humanismo, Marx rompe definitivamente com toda forma de idealismo, sendo célebre a sua crítica aos filósofos que se propunham "interpretar" o mundo de diferentes maneiras, enquanto ele afirma que o que lhe interessava mesmo era cuidar de "transformá-lo". O método dialético herdado de Hegel não podia, pois, ficar circunscrito à dimensão especulativa, no campo das idéias. Ao contrário, deveria proporcionar uma enérgia prática, sendo hábil a traduzir e explicar as leis empiricamente observáveis nas relações do homem com a natureza e com os outros homens. Nessa ótica não sobra qualquer espaço para a consideração de uma dimensão espiritual do homem, fator esse que representa inequívoco reducionismo que, segundo os autores cristãos, acabará por comprometer seriamente a pretensão de oferecer resposta integral e satisfatória para o problema da realização plena do ser humano.

Mas, continuando a investigação acerca da concepção de Marx a respeito do homem, temos que esse pensador vislumbrava no trabalho, no ato de produzir, a verdadeira essência do ser humano, e até mesmo a sua origem. Propõe, ainda, que a explicação do ser do homem somente seria possível no curso da história. Assim se expressa o próprio Marx (2004, p. 114), nos seus "Manuscritos Econômicos e Filosóficos":

toda a assim chamada história mundial nada mais é do que o engendramento (criação) do homem mediante o trabalho humano, enquanto o vir a ser da natureza para o homem; então ele tem, portanto, a prova intuitiva, irrefutável, do seu nascimento por meio de si mesmo (autocriação), do seu processo de geração.

A produção é, portanto, o ato fundamental, é a raiz da história humana. Produzir ${ }^{5}$ é a atividade radical da humanidade. Pela produção é que o homem se sustenta e se faz. E a história não faz outra coisa senão manifestar a maneira como os homens produzem. $\mathrm{O}$ homem mantém sua existência, e satisfaz suas necessidades pela produção. Por isso é que Marx considera a produção o "primeiro ato histórico". Como ensina Juvenal Arduini (1965, p. 131) “o humanismo marxista está precisamente na produção do homem pelo homem,

\footnotetext{
${ }^{4}$ Tal como consta na décima primeira tese sobre Feuerbach.

${ }^{5}$ Produção no sentido material, econômico, concreto. Essa dimensão material é que determina ( ou condiciona, de forma quase fatal) a história, segundo Marx, a partir dos conflitos e antagonismos entre a chamada infraestrutura e a superestrutura.
} 
através da mediação do trabalho, pelo qual tudo se torna social, e, por isso mesmo, humano". Como explica esse mesmo autor, na perspectiva marxista é através da produção real, liberta da alienação, que o homem apropria-se de sua essência em todas as dimensões, e reencontra o seu ser e o ser do outro.

Assim, resta patente que um aspecto muito importante do humanismo marxista encontra-se exatamente na valorização do trabalho humano. É no trabalho que se "define" o homem, distiguindo-o dos demais animais. Marx (1996, pp. 297-298) esboçou sua concepção do trabalho numa célebre página do Capital:

Antes de tudo, o trabalho é um processo entre o homem e a Natureza, um processo em que o homem, por sua própria ação, media, regula e controla seu metabolismo com a Natureza. Ele mesmo se defronta com a matéria natural como uma força natural. Ele põe em movimento as forças naturais pertencentes a sua corporalidade, braços e pernas, cabeça e mão, a fim de apropriar-se da matéria natural numa forma útil para sua própria vida. Ao atuar, por meio desse movimento, sobre a Natureza externa a ele e ao modificá-la, ele modifica, ao mesmo tempo, sua própria natureza. Ele desenvolve as potências nela adormecidas e sujeita o jogo de suas forças a seu próprio domínio. Não se trata aqui das primeiras formas instintivas, animais, de trabalho. $O$ estado em que o trabalhador se apresenta no mercado como vendedor de sua própria força de trabalho deixou para o fundo dos tempos primitivos o estado em que o trabalho humano não se desfez ainda de sua primeira forma instintiva. Pressupomos o trabalho numa forma em que pertence exclusivamente ao homem. Uma aranha executa operações semelhantes às do tecelão, e a abelha envergonha mais de um arquiteto humano com a construção dos favos de suas colmeias. Mas o que distingue, de antemão, o pior arquiteto da melhor abelha é que ele construiu o favo em sua cabeça, antes de construí-lo em cera. No fim do processo de trabalho obtém-se um resultado que já no início deste existiu na imaginação do trabalhador, e portanto idealmente.

Apesar dessa elevada dignidade do trabalho, muitas vezes o trabalhador é compelido a trabalhar instintivamente, como um animal. Tal era a situação observada por Marx em grande parte das fábricas inglesas em meados do século XIX. O trabalhador era reduzido a condições tão vis e degradantes que seu trabalho perdia a característica humana, sendo reduzido a níveis de irracionalidade. O trabalhador não mais se reconhecia no seu trabalho, torna-se estrangeiro a si próprio, eis aí o homem alienado de sua própria criação. Deparando-se com esse quadro é que Marx desenvolve toda sua doutrina econômico-política, na pretensão de libertar o homem de todas essas opressões.

Entretanto, segundo muitos pensadores que se aprofundaram sobre a obra de Karl Marx, haveria uma cisão ou ruptura expressiva no pensamento marxista a partir da elaboração de "A Ideologia Alemã" (em 1845), particularmente quanto à maneira de considerar ou de 
reconhecer o valor relativamente autônomo do indíviduo. Com isto seu humanismo teria “empobrecido". Segundo Pedro Nogare (1983, pp. 104 e 109), a originalidade dos escritos do jovem Marx estaria

no fato de apresentarem eles como preocupação fundamental a libertação do homem - do trabalhador enquanto representante de todos os homens - das múltiplas alienações em que se encontra coisificado. Enquanto, nos escritos posteriores do Marx adulto, a preocupação é compreender o processo histórico, inserir-se nele e colaborar com ele, para levar a humanidade à libertação final, ficando o indivíduo esquecido diante dessa tarefa." (...) "Marx a um certo momento de sua vida teria descoberto que as categorias humanistas: homem, natureza humana, essência humana, subjetividade, objetivação, alienação, etc, não lhe ofereciam nenhuma utilidade para conhecer e resolver os problemas da sociedade e, portanto, dos homens. Só na condição de servir-se dos conceitos, de formação social, forças produtivas, modo de produção, etc, ele poderia realizar seu plano de construir uma teoria realista da sociedade" ${ }^{6}$.

Haveria, então, uma contradição na expressão "humanismo socialista" pois, segundo o marxismo autêntico o conceito de socialismo é um conceito científico enquanto que o conceito de humanismo seria ideológico. Em "A Ideologia Alemã" fica patente que Marx pretendeu se despojar de toda concepção idealista, ou melhor, das "fraseologias" que não teriam o condão de interferir sobre o mundo real. Pelo contrário, elas é que são produto do estado de alienação em que se encontra(va) a humanidade escravizada pelo modo de produção capitalista. No lugar dessas concepções radicadas em "fraseologias", que "falseam" a realidade, Marx propunha uma nova abordagem baseada na praxis, na história efetivamente construída pelo trabalho cotidiano dos homens, na sua experiência vivida dia a dia, único critério considerado por ele como verdadeiro.

A afirmação de um humanismo marxista importa, pois, necessariamente em identificar na concepção de Marx o que entendia ser a "verdade" do homem, a sua essência. A resposta para essa questão encontra-se nitidamente presente nesse contexto de ruptura epistemológica. Daí é que se pode compreender o significado da afirmação contida na sexta tese sobre

\footnotetext{
${ }^{6}$ Dentre os autores marxistas invocados pelo Prof. Nogare para respaldar essas considerações está o francês Louis Althusser, que chega a usar a expressão "anti-humanismo teórico" para caracterizar essa perspectiva do pensamento marxista. Parece oportuno reproduzir aqui o trecho citado por Nogare, de autoria de Althusser: "Sob a relação estrita da teoria, pode-se e deve-se então falar abertamente de um anti-humanismo teórico de Marx, e ver nesse anti-humanismo teórico a condição de possibilidade absoluta (negativa) do conhecimento (positivo) do próprio mundo humano e da sua transformação prática. Só se pode conhecer qualquer coisa dos homens na condição absoluta de reduzir a cinzas o mito filosófico (teórico) do homem. Todo pensamento que então se pretendesse fundado em Marx para restaurar de uma ou de outra maneira uma antropologia ou um humanismo teóricos seria teoricamente reduzido a cinzas. Mas praticamente poderia edificar um monumento de ideologia pré-marxista que pesaria na história real, e correria o risco de arrastá-la a impasses" (Apud NOGARE, 1983, p. 109).
} 
Feuerbach: "a essência humana não é uma abstração inerente ao indivíduo singular. Em sua realidade, é o conjunto das relações sociais". Isto quer dizer, segundo ensina Adolfo Vasquez (1977, p. 423), que a essência humana

\begin{abstract}
não pode se manifestar fora das relações reais, dos homens, e tampouco nos indivíduos isolados nem em sua totalidade, essa essência que só se manifesta socialmente é a prática - isto é, a prática que fundamenta e torna possível todo tipo de atividade humana. O homem é, essencialmente, um ser prático, produtor. A produção - e em primeiro lugar a produção material - eis o que determina a existência da sociedade humana em seu conjunto e de cada indivíduo humano, assim como a própria história.
\end{abstract}

Temos aqui, ressalte-se, um humanismo que necessariamente coincide com um materialismo historicista. Tal postura de Marx, ainda que seja a única coerente com a linha argumentativa de suas reflexões e conclusões, suscita uma preocupação grave sobre as possibilidades que desperta de manipulação do ser humano. Na medida em que afasta a dimensão espiritual e transcedental do homem, reduzindo-o à realidade física e material, e conferindo uma proeminência à dimensão material-econômica da existência humana, acaba por cometer uma "inversão" que se traduz no "endeusamento" da produção, compromentendo toda a riqueza e grandeza de suas descobertas sobre o valor e o significado do trabalho e a importância da dimensão social para o indivíduo. Voltaremos a esse assunto, quando passarmos ao estudo da crítica que a antropologia cristã oferece ao pensamento de Marx.

Para concluir esta reflexão acerca do humanismo marxista, e compreender melhor as razões que teriam levado Marx a, de certa maneira, reformular seu pensamento de modo talvez até um pouco contraditório - se confrontado com seus escritos de juventude enfatizando a dimensão material e histórica na sua proposta de "transformação" do mundo, impõe-se considerar que a atitude de Marx, ao que parece, não teria sido motivada por um deliberado menosprezo dos valores e da dignidade da pessoa humana. Pelo contrário, tudo indica que essa nova diretriz assumida por Marx tenha decorrido da compreensão de que os males que afligiam (e ainda afligem) a humanidade não seriam resolvidos por formulações teóricas, ou especulações metafísicas. Essas "fraseologias" poderiam até ser muito bem articuladas e convincentes, mas sem uma atitude prática, concreta, sem uma "conscientização" que se traduzisse em atos não adiantaria em nada para efetivamente resgatar o homem das horrendas situações opressivas a que estava submetido. Ou melhor, Marx teria compreendido que "não basta o humanismo ideológico para libertar o homem: é preciso que a ciência sugira 
os caminhos e aponte os meios" (NOGARE, 1983, p. 111). É preciso que o homem assuma as "rédeas" de seu destino. Aqui está, sem dúvida, uma das mais importantes contribuições do marxismo para a humanidade.

\section{Considerações Críticas sobre o Humanismo Marxista na perspectiva da Antropologia Cristã}

Traçando um paralelo entre o projeto marxista de realizar a libertação do homem das diversas formas de alienação que o "desumanizam", que o escravizam, privando-o de sua própria essência, podemos observar que tal pretensão guarda inequívoca equivalência com o projeto de diversas correntes religiosas, culminando numa efetiva aproximação daquilo que o cristianismo prega há dois milênios: em Jesus Cristo a humanidade descobre a Verdade sobre si mesma e sobre seu Criador, reencontrando-se com sua essência, e estabelecendo-se definitivamente o traço de união entre a dimensão corporal e a dimensão espiritual do homem, realizando-se sua efetiva libertação. Como ensina São João, no Evangelho: "Conhecereis a Verdade, e a Verdade vos libertará" - Jo 8, 32.

Todavia essa coincidência é apenas aparente. O humanismo marxista e o humanismo cristão encontram-se em profundo antagonismo. Isto porque para o marxismo só existe "autêntico" humanismo dentro do ateísmo radical, enquanto que para o cristianismo é impossível um verdadeiro humanismo sem a relação fundamental do homem com o Absoluto, com seu Criador. Como havíamos considerado na introdução deste trabalho, tudo gira em torno do equilíbrio entre uma cosmovisão antropocêntrica ou teocêntrica. Por sua vez, a redução da essência do homem à condição de mero reflexo das relações sociais de produção como concebe o marxismo - suscita distorções e equívocos que, na perspectiva cristã, jamais poderão contribuir para ressaltar o valor intrínseco da pessoa humana. A identificação do indivíduo ao todo, ao coletivo - que seria a meta alcançável no estágio final da sociedade comunista - traduz-se, segundo a antropologia cristã, num grave desequilíbrio entre as dimensões individual e coletiva, que comprometeria radicalmente a possibilidade de um humanismo marxista. Na proposta de Marx a coletividade humana seria reduzida a uma só pessoa. Essa abstração de reduzir a humanidade à unidade representaria um inequívoco desprezo pela dimensão individual do homem, dimensão essa que não pode ser afastada das pretensões efetivas de proporcionar a plena realização do ser humano. 
É incontestável que Marx tentou eliminar de sua afirmação do homem e de sua dignidade essencial as categorias éticas, metafísicas e religiosas. Todavia fica patente uma contradição ínsita na sua lógica. Assim, ao afirmar que nas filosofias idealistas e nos modelos de pensamento baseados em pressupostos de ordem religiosa que lhe antecederam haveria uma "inversão" na relação do homem para com a natureza e de uma "perversão" na relação do homem para com seu semelhante, surgem fatalmente as seguintes questões postas por Pierre Bigo (1986, p. 191):

Como pensar numa inversão consistindo em que as coisas dominam o homem em lugar de serem dominadas por ele, se a realidade vaza-se num molde monista, se tudo tem igual valor nesta realidade, se nela não existe uma pluralidade fundamental de elementos e uma hierarquia? (...) Como pensar numa tal inversão e perversão da relação humana, sem afirmar o homem, ao mesmo tempo, como ente espiritual e como ser moral, sem passar do domínio da existência e do valor??

Enfim, parece impossível ignorar que, no contexto de sua economia política, Marx jamais teria conseguido efetivamente escapar de uma conotação metafísica - ou metaeconômica, expressão que parece mais adequada, no caso.

Mas, voltando à questão do ateísmo marxista, sobre o qual pesam as mais contundentes críticas da antropologia cristã, muitos procuram compreender qual seria a causa desse verdadeiro ódio manifestado por Marx contra a religião, que, de certo modo, acabou provocando severas restrições que limitaram a aceitação, suscitando enorme preconceito contra sua teoria econômica. Alguns autores tentam buscar explicação para essa atitude de Marx na sua vida pessoal. Marx era filho de judeus convertidos ao protestantismo por conveniência política, e vivia num ambiente de flagrante irreligiosidade. Cresceu num clima de agnosticismo e ateísmo, sendo que as deturpações do cristianismo com que se deparava na sua experiência concreta traduziram-se numa verdadeira caricatura da religião, contra a qual se insurge. Assim, a vida religiosa, mesmo a mais autêntica, e que muitas vezes tem sido de

\footnotetext{
${ }^{7}$ Mais adiante, nessa mesma obra (p. 194), o autor apresenta um interessante paralelismo onde revela que a doutrina marxista estaria intrinsecamente revestida de inequívoco caráter religioso. Vejamos suas palavras: "O proletário está no centro da história, como Cristo entre o Começo e o Fim dos Tempos. Há, em Marx, uma Gênese: o ato criador, que é o trabalho, está estreitamente ligado ao ato da alienação do homem no trabalho. O pecado está nas próprias origens da humanidade. Há também um Apocalipse. O homem deve reencontrar, através de uma catástrofe, o paraíso perdido. Egresso, pelo pecado capitalista, de um estado econômico primitivo, onde tudo era humano, onde os homens tinham, uns para com os outros, seu aspecto humano, o homem deve atingir, por meio de de um 'desenvolvimento longo e doloroso' (O Capital, T. I, p. 96), um estado novo, onde a inocência primitiva será devolvida, com uma riqueza que ele não teria nunca conhecido sem a falta, a felix culpa. O advento da sociedade sem classes marcará o fim de toda alienação, o fim de toda oposição". Daí, talvez a razão pela qual o marxismo militante teria assumido conotações de cunho verdadeiramente sectário, como registra especialmente a história do século XX.
} 
grande eficácia para a libertação do homem e para a comunhão humana, é condenada da mesma maneira que suas formas corrompidas. Como observa Juvenal Arduini (1965, p. 21), Marx “odeia o genuino através do desfigurado", muito embora, ainda segundo Arduini, "muito do que existe de objetivamente humano em Marx, não lhe teria sido comunicado pelo ateísmo, mas pelo evangelho de Cristo, difuso no ambiente da época. O marxismo seria, então, um arremedo brutal do Cristianismo"

O fato é que, se na lógica marxista o ateísmo deveria surgir "espontaneamente", tão logo cessada a alienação econômica e, por conseqüência, a alienação religiosa, em virtude da própria dialética materialista da história, o marxista militante sempre se viu assustado com o problema da religião, procurando por todos os meios combatê-la e denegrí-la numa verdadeira obsessão, atitude que revela mais uma contradição intrínseca no marxismo, uma vez que parece não acreditar verdadeiramente que Deus será eliminado da história humana apenas por decorrência da dialética econômica, como consta dos escritos de Marx. Aqui se encontra, pois, mais um sofisma em que incorreu Marx, na medida em que recusou-se a reconhecer que a dimensão religiosa transcende as estruturas econômicas. De qualquer maneira, a crítica de Marx e de seus seguidores traduziu-se numa importante oportunidade para que fossem desmascaradas as atitudes falsas do homem em relação a Deus, despertando a atenção de muitas pessoas que efetivamente queriam vivenciar uma autêntico cristianismo para deixar a atitude de comodismo em que se encontravam e assumir compromissos efetivos com o verdadeiro projeto libertador proclamado pelo Cristo.

Além da crítica elaborada a partir das premissas teóricas do pensamento de Marx, também uma análise dos efeitos práticos advindos da adoção desses postulados, tal como historicamente se viram aplicados, acaba por ressaltar ainda mais esse profundo antagonismo entre a perspetiva antropológica cristã e o marxismo. Com efeito, se por um lado é lícito reconhecer que os países que implantaram regimes baseados na doutrina marxista alcançaram consideráveis níveis de justiça social e razoáveis padrões de igualdade no acesso aos bens materiais e satisfação das necessidades básicas do ser humano, tais resultados não foram suficientes para aplacar os anseios de liberdade e auto-determinação, de autonomia em face do autoritarismo e do totalitarismo estatal, vigorando um clima de terror e perseguição contra

\footnotetext{
${ }^{8}$ Noutra passagem de seu livro, Arduini menciona que Marx teria se utilizado da alegoria do mito de Prometeu para expressar sua rebeldia contra os deuses e a religião. Por ter se recusado a manter-se submisso a Zeus, Prometeu teve de suportar o terrível suplício de ser devorado em suas entranhas por um abutre. Por isso Marx o enaltecia, considerando-o "o primeiro mártir do calendário filosófico" (ARDUINI, 1965, p. 131). Todavia, ainda segundo este autor, tal alegoria não cabe jamais numa interpretação do cristianismo pois "O Deus do cristianismo não é um abutre que devora as entranhas humanas, mas é um Cordeiro que se sacrifica para reconciliar seus irmãos"(idem, p. 193).
} 
aqueles que assumissem uma posição de crítica ou oposição aos líderes e burocratas que ocupavam os postos de direção, num ambiente de violência e conflitos intermináveis cuja imagem simbólica mais expressiva foi o chamado "Muro de Berlim", que acabou vindo abaixo no ano de 1989. Esta constatação revela que, também no âmbito da experiência real, o marxismo foi incapaz de proporcionar a plena realização do ser humano, razão pela qual, inclusive, vem cada vez perdendo mais prestígio como alternativa efetiva no quadro político das diversas nações da terra.

Finalmente, como última questão a ser abordada, para encerrar este estudo cujas dimensões são, deliberadamente, limitadas, como acentuávamos na introdução, verificamos que a própria maneira de considerar a liberdade, na ótica marxista, revela essa frontal oposição quanto à antropologia cristã. Marx considerava a liberdade mais como uma situação econômica da liberdade do que como um atributo da pessoa. $\mathrm{O}$ homem alienado economicamente jamais poderia ser considerado livre, ficando em segundo plano a questão da liberdade psicológica. O homem, segundo Marx, não é livre para planejar a história tal como a deseja: isto seria impossível, em virtude do materialismo dialético determinista, restando-lhe tão somente a prerrogativa de "libertar-se" das diversas formas de alienação, tomando consciência do processo histórico e cooperando efetivamente para a construção da sociedade comunista. Daí resultam duas conseqüências antagônicas: se por um lado o indivíduo é estimulado a sair do comodismo e assumir uma atitude prática em busca de sua libertação, por outro lado fica patente uma terrível "mutilação antropológica através do estrangulamento da autonomia humana" (ARDUINI, 1965, p. 125).

\section{Considerações Finais}

A antropologia cristã é caracterizada pela afirmação de uma verdade elementar: o homem tem uma radical primazia sobre as coisas; apesar de ser integrante da natureza, o homem a transcende, na medida em que comporta em sua essêcncia uma dimensão corporal e uma dimensão espiritual indissociáveis. Se para saciar seus anseios de ordem material, é necessário proporcionar o incremento das relações de produção material e garantir seu equitativo proveito em favor de todos aqueles que - pelo trabalho - tomam parte nesse processo produtivo, o preenchimento de suas necessidades de ordem espiritual e transcedental somente será atingido plenamente com o estabelecimento de uma relação com o Absoluto, visto que o ser humano, no mais profundo de seu âmago, clama por valores infinitos, imateriais, que somente poderão ser saciados na divindade. Portanto, na visão cristã, 
a partir do momento em que concebe a realidade humana sob uma ótica estritamente materialista e professa um ateísmo radical, o marxismo assume uma feição que torna incompatível a possibilidade de realização de um autêntico humanismo.

O Marxismo é indissociável de sua base materialista atéia, e portanto, nesses aspectos, incompatível com a antropologia cristã. Isto não quer dizer que os cristãos devam fazer uma tábula rasa de todas as proposições de Marx ignorando sua importante contribuição para uma crítica do capitalismo, sobretudo quando denuncia a miséria injusta gerada pela exploração impiedosa do homem pelo homem, e quando propõe a necessidade de construir uma nova estrutura que venha superar todas essas degradações a que tem sido submetido o ser humano. O próprio Papa João Paulo II, na sua Encíclica Redemptor Hominis ( $\mathrm{n}^{\circ}$ 15), reconheceu a pertinência de certas constatações de Marx, quando afirmou que "o capítulo principal do drama da existência humana contemporânea" encontra-se no fato de que "o homem de hoje parece estar sempre ameaçado por aquilo mesmo que produz", assimilando ainda o termo marxista "alienação", para demonstrar que hoje em dia apresenta uma conotação muito mais ampla do que a que fora inicialmente proposta por Marx. Em outra ocasião, no discurso pronunciado em 02 de junho de 1980 perante a UNESCO, em Paris, o mesmo Papa João Paulo II admitiu que o critério "das relações de produção que prevalecem em uma determinada época, constitui de fato uma chave, e chave importante. Porém não é a chave fundamental, constitutiva. Não é tal ou qual sistema que está na base da cultura, mas o mesmo homem que vive neste sistema."

Enfim, enfatizando as deficiências do capitalismo liberal e individualista, e expurgando do marxismo (se é que seja possível ) a sua dimensão de materialismo ateu, totalitarista e coletivista, o cristianismo convoca os homens de boa vontade para que se aliem na construção uma sociedade fundada, como explicitam Pierre Bigo e Fernando Bastos de Ávila (1986), sobre a base da verdade e do direito, que não se determine apenas pela eficiência da produção e na luta de classes. E, concluímos nós, usando as palavras desses mesmos autores (1986, p. 328):

A fé no homem, que se baseia na fé cristã e que não é monopólio do cristão, conduz a uma concepção do homem irredutível ao simplesmente individual ou ao simplesmente coletivo; leva à concepção de um homem pluridimensional; fundamenta uma antropologia radicalmente distinta da antropologia capitalista ou marxista, ambas atéias; obriga o cristão a não ser passivo, mas ativo, inventivo, na sua análise e na sua práxis, se deseja sinceramente a libertação autêntica do homem. 


\section{Referências Bibliográficas}

ARDUINI, Juvenal. O Marxismo. Rio de Janeiro, Agir, 1965.

BIGO, Pierre; AVILA, Fernando de Bastos. Fé Cristã e Compromisso Social. São Paulo, Paulinas, $3^{a}$ ed., 1986.

BIGO, Pierre. Marxismo e Humanismo. São Paulo, Herder, 1966.

FEUERBACH, Ludwig. A Essência do Cristianismo. Tradução e notas de José da Silva Brandão. Petrópolis, Vozes, 2007.

KONDER, Leandro. Marx: Vida e Obras. Rio de Janeiro, Paz e Terra, 4ª ed., 1981.

LUBAC, Henri de. Le drame de l'humanisme athée. Paris, Spes, 3a ed., 1945.

MARX, Karl; ENGELS, Friedrich. A Ideologia Alemã. Tradução de Jose Carlos Bruni e Marco Aurélio Nogueira. São Paulo, Hucitec, 10ª ed., 1996.

MARX, Karl; ENGELS, Friedrich. La Sagrada Familia. Version castellana por Carlos Liacho. Buenos Aires, Editorial Claridad, 2a ed., 1971.

MARX, Karl. Manuscritos Econômico-Filosóficos. Tradução de Jesus Ranieri. São Paulo, Boitempo, 2004.

MARX, Karl. O Capital. Tradução Regis Barbosa e Flavio R Kothe. Coleção: Os Economistas. São Paulo, Nova Cultural, 1996.

MARX, Karl. Para a Crítica da Economia Política. Coleção: Os Pensadores - no 16. São Paulo, Nova Cultural, 1997.

NOGARE, Pedro Dalle. Humanismos e Anti-humanismos. Petrópolis, Vozes, $8^{a}$ ed., 1983.

NOGUEIRA, Alcântara. Poder e Humanismo. Porto Alegre, Sergio Antonio Fabris, 1989.

VAZQUEZ, Adolfo Sánchez. Filosofia da Praxis. Rio de Janeiro, Paz e Terra, 2a ed., 1977.

WEFORT, Francisco C. "Marx: Política e Revolução” In: WEFORT, Francisco C. Os Clássicos da Política - vol 2. São Paulo, Atica, $5^{a}$ ed., 1995.

WOZNICKI, Andrew N. Un Humanismo Cristiano: El personalismo existencial de Karol Wojtyla. Lima, VE, 1988.

YURRE, Gregorio Rodriguez de. "El hombre en el seno del comunismo". In: LADUSÃNS, Stanislaws. A análise Social Filosófico-cristã. Rio de Janeiro, Presença, 1988. 